\title{
Characterization of Polymorphic Microsatellite Markers Isolated from Genomic DNA of Elaeocarpus decipiens Hemsly (Elaeocarpaceae)
}

\section{Xi Gong ${ }^{1 *}$ and Gang $\mathrm{Ge}^{2}$}

${ }^{1}$ College of Life Sciences and Food Engineering, Nanchang University, Nanchang 330047, China

${ }^{2}$ Key Laboratory of Plant Resources, Jiangxi Province, College of Life Sciences and Food Engineering, Nanchang University, Nanchang 330031, China

\begin{abstract}
The development of compound microsatellite markers was conducted in Elaeocarpus decipiens to investigate genetic diversity and population genetic structure of this species. Eighteen microsatellite markers that were successfully amplified showed polymorphism when tested on 35 individuals from three populations in Chinese mainland. Overall, the number of alleles per locus ranged from 4 to 11 , with an average of 7.06 alleles per locus. These results indicate that these microsatellite markers are adequate for detecting and characterizing population genetic structure and genetic diversity in E. decipiens. Of these primers, only four could be successfully transferred to E. sylvestris and E. japonicus.
\end{abstract}

Keywords: Elaeocarpus decipiens; Microsatellite markers; Genomic DNA; Genetic diversity

\section{Introduction}

Elaeocarpus decipiens is an evergreen, broad-leaved, woody species of the Elaeocarpaceae family with a disjunct distribution in south of Chinese mainland, the Ryukyu Archipelago and Taiwan. Currently, most of the efforts have been focused on the germplasm, breeding and cultivation of this species [1]. The study of population genetic diversity, population genetic structure and population ecology of this species is insufficient and limited. However, population genetic analysis of this disjunct plant will potentially provide insights into the geographic structure of genetic diversity that reflects the evolutionary history of E. decipiens. To assess gene flow across the populations and to infer biogeographic patterns, we developed microsatellite markers for this species, for which none were available previously. Additionally, these loci were tested for cross-amplification in E. sylvestris and E. japonicas.

\section{Materials and Methods}

Genomic DNA of $E$. decipiens was extracted from fresh leaves using a modified CTAB (cetyltrimethyl ammonium bromide) method [2]. An adaptor-ligated DNA library was constructed following the protocol of Lian et al. [3]. Briefly, total genomic DNA $(10 \mu \mathrm{g})$ was digested with a blunt-end restriction enzyme, EcoRV (Takara, Dalian, Liaoning, China), and the restricted fragments were ligated to an unequal-length adaptor, using DNA Ligation Kit Version 2.0 (Takara, Dalian, Liaoning, China). Then, fragments flanked by a microsatellite at one end were amplified from the EcoRV DNA library using compound SSR primer $(\mathrm{AC})_{6}(\mathrm{AG})_{5}$ and an adaptor primer AP2 (5'-CTATAGGGCACGCGTGGT- $\left.3^{\prime}\right)$. The recovered DNA was ligated into a pGEM-T vector (Promega, Madison, Wisconsin, USA), and transformed into DH5 a competent cells (Takara, Dalian, Liaoning, China). Transformants were cultured on selective agar media with ampicillin, X-Gal and IPTG, for blue/white colony selection. After PCR-tested for insert size of the white colonies, a total of 144 clones were found to contain $(\mathrm{AC})_{6}(\mathrm{AG})_{\mathrm{n}}$ compound SSR motifs. 55 sequences were too short to design primer. And 89 clones proved suitable for primer design using PREMIER version 5.0 [4]. These primers were tested for polymorphism in E. decipiens. A total of 53 out of the 89 primer pairs tested successfully amplified the target fragments. PCR was performed in $10-\mu \mathrm{L}$ reaction volumes containing $30-50 \mathrm{ng} /$ $\mu \mathrm{L}$ of template DNA, 0.25 unit Taq DNA polymerase (TaKaRa, Dalian, Liaoning, China), $1 \mu \mathrm{L} 10 \times$ PCR buffer, $0.5 \mu \mathrm{L}$ of $2.5 \mathrm{mM} \mathrm{MgCl}, 1 \mu \mathrm{L}$ of $2.5 \mathrm{mM}$ dNTPs, $0.05 \mu \mathrm{L}$ bovine serum albumin (BSA) (TaKaRa, Dalian,
Liaoning, China), and $0.6 \mu \mathrm{L}$ of each $10 \mu \mathrm{M}$ primer. The thermal profile used was initial denaturing for $5 \mathrm{~min}$ at $95^{\circ} \mathrm{C}$, followed by 30 cycles of $30 \mathrm{~s}$ at $95^{\circ} \mathrm{C}, 45 \mathrm{~s}$ of annealing at the optimized annealing temperature (Table 1), $1 \mathrm{~min} 30 \mathrm{~s}$ of elongation at $72^{\circ} \mathrm{C}$, ending with a 10 -min extension at $72^{\circ} \mathrm{C}$. The forward primer of each pair was labeled with a fluorescent dye (6-FAM). Products were resolved using an ABI 3730 sequencer (Applied Biosystems), along with a fluorescently labeled internal size standard (GeneScan 500 LIZ Size Standard; Applied Biosystems), and the samples were genotyped using GENEMAPPER version 4.0 (Applied Biosystems).

Polymorphisms of these primers were assessed in 35 natural individuals of E. decipiens collected from Jinggang Mountain (JG, $\left.26^{\circ} 35^{\prime} 19^{\prime \prime} \mathrm{N}, 114^{\circ} 07^{\prime} 39^{\prime \prime} \mathrm{E}\right)$, Laohunao Mountain (LHN, $27^{\circ} 13^{\prime} 18^{\prime \prime} \mathrm{N}$, $116^{\circ} 00^{\prime} 43^{\prime \prime}$ E) and Tongbo Mountain (TB, 28 $04^{\prime} 57^{\prime \prime}$ N, $118^{\circ} 14^{\prime} 18^{\prime \prime}$ E). Voucher specimens for the sampled populations are stored at the Herbarium of Nanchang University (JXU). Parameters of genetic diversity including the expected heterozygosity $(\mathrm{He})$ and observed heterozygosity $(\mathrm{Ho})$, number of alleles $(A)$ per locus, tests for linkage disequilibrium (LD), and deviation from Hardy-Weinberg equilibrium (HWE) were calculated using GENEPOP version 4.0.7 [5]. In addition, CERVUS version 3.0.3 [6] was employed to calculate the value of polymorphic information content (PIC).

\section{Results}

Eighteen out of the 53 loci were identified as polymorphisms and generated consistent amplification products of the expected size range (Table 1). These loci contained 4 to 11 alleles in the 35 individuals, with $\mathrm{He}$ and Ho ranging from 0.685 to 0.909 and from 0.583 to 0.917 , respectively. On average, the PIC were 0.747 (range: $0.627-0.854$ ), 0.756 (range: $0.654-0.845$ ) and 0.751 (range: $0.605-0.850$ ) for populations

*Corresponding author: Xi Gong, College of Life Sciences and Food Engineering, Nanchang University, Nanchang 330047, China, E-mail: gongxi413@163.com

Received September 11, 2013; Accepted October 07, 2013; Published October 10,2013

Citation: Gong X, Ge G (2013) Characterization of Polymorphic Microsatellite Markers Isolated from Genomic DNA of Elaeocarpus decipiens Hemsly (Elaeocarpaceae). J Data Mining Genomics Proteomics 4: 141. doi:10.4172/21530602.1000141

Copyright: ( 2013 Gong X, et al. This is an open-access article distributed under the terms of the Creative Commons Attribution License, which permits unrestricted use, distribution, and reproduction in any medium, provided the original author and source are credited. 
Citation: Gong X, Ge G (2013) Characterization of Polymorphic Microsatellite Markers Isolated from Genomic DNA of Elaeocarpus decipiens Hemsly (Elaeocarpaceae). J Data Mining Genomics Proteomics 4: 141. doi:10.4172/2153-0602.1000141

Page 2 of 3

\begin{tabular}{|c|c|c|c|c|c|c|c|}
\hline Locus & Repeat & Primer sequence $\left(5^{\prime}-3^{\prime}\right)$ & s & $\operatorname{Ta}\left(\mathrm{C}^{\circ}\right)$ & $A$ & GenBank & Cross-amplification \\
\hline Ed1 & $(\mathrm{AC})_{6}(\mathrm{AG})_{17}$ & $\begin{array}{l}\text { F: ACACACACACACAGAGAGAGAG } \\
\text { R: CTGATGTTGCCACGGAGT }\end{array}$ & $\begin{array}{l}277 \\
265-303\end{array}$ & 54 & 10 & JX193598 & \\
\hline Ed2 & $(\mathrm{AC})_{6}(\mathrm{AG})_{7}$ & $\begin{array}{l}\text { F: ACACACACACACAGAGAGAGAG } \\
\text { R: TCAAAACACAAAAAAACTCA }\end{array}$ & $\begin{array}{l}171 \\
167-194\end{array}$ & 52 & 9 & JX193599 & \\
\hline Ed3 & $(\mathrm{AC})_{6}(\mathrm{AG})_{6}$ & $\begin{array}{l}\text { F: ACACACACACACAGAGAGAGAG } \\
\text { R: ATACAAATTGAACAAGGGCTTA }\end{array}$ & $\begin{array}{l}314 \\
312-330\end{array}$ & 53 & 8 & JX193600 & \\
\hline Ed4 & $(A C)_{6}(A G)_{6}$ & $\begin{array}{l}\text { F: ACACACACACACAGAGAGAGAG } \\
\text { R: AGTTTGAGGCTTTATTCAGTTT }\end{array}$ & $\begin{array}{l}213 \\
211-225\end{array}$ & 54 & 5 & JX193601 & \\
\hline Ed5 & $(\mathrm{AC})_{6}(\mathrm{AG})_{7}$ & $\begin{array}{l}\text { F: ACACACACACACAGAGAGAGAG } \\
\text { R: ACAGGGTTCTTGCTATTTCA }\end{array}$ & $\begin{array}{l}187 \\
185-218\end{array}$ & 53 & 7 & JX193602 & \\
\hline Ed6 & $(A C)_{6}(A G)_{9}$ & $\begin{array}{l}\text { F: ACACACACACACAGAGAGAGAG } \\
\text { R: GCCACCAATCCTTGAACCT }\end{array}$ & $\begin{array}{l}175 \\
169-212\end{array}$ & 54 & 9 & JX193603 & $a, b$ \\
\hline Ed7 & $(\mathrm{AC})_{6}(\mathrm{AG})_{7}$ & $\begin{array}{l}\text { F: ACACACACACACAGAGAGAGAG } \\
\text { R: TGTCATTGATGGGAAAAACT }\end{array}$ & $\begin{array}{l}291 \\
289-334\end{array}$ & 53 & 10 & JX193604 & \\
\hline Ed8 & $(\mathrm{AC})_{6}(\mathrm{AG})_{11}$ & $\begin{array}{l}\text { F: ACACACACACACAGAGAGAGAG } \\
\text { R: AAATGTCATAATCAAAAAGCAG }\end{array}$ & $\begin{array}{l}134 \\
124-154\end{array}$ & 51 & 9 & JX193605 & \\
\hline Ed9 & $(\mathrm{AC})_{6}(\mathrm{AG})_{6}$ & $\begin{array}{l}\text { F: ACACACACACACAGAGAGAGAG } \\
\text { R: TGATTCTTGATGTCCTTCTATT }\end{array}$ & $\begin{array}{l}179 \\
177-199\end{array}$ & 54 & 5 & JX193606 & $a$ \\
\hline Ed10 & $(\mathrm{AC})_{6}(\mathrm{AG})_{9}$ & $\begin{array}{l}\text { F: ACACACACACACAGAGAGAGAG } \\
\text { R: GCTTTTGAGGGCTATTGATG }\end{array}$ & $\begin{array}{l}216 \\
208-232\end{array}$ & 54 & 8 & JX193607 & \\
\hline Ed11 & $(\mathrm{AC})_{6}(\mathrm{AG})_{11}$ & $\begin{array}{l}\text { F: ACACACACACACAGAGAGAGAG } \\
\text { R: CATCACCTTTTTCCCTATCA }\end{array}$ & $\begin{array}{l}402 \\
394-418\end{array}$ & 53 & 5 & JX193608 & $a, b$ \\
\hline Ed12 & $(\mathrm{AC})_{6}(\mathrm{AG})_{6}$ & $\begin{array}{l}\text { F: ACACACACACACAGAGAGAGAG } \\
\text { R: TCGGGAATGAAAAAAAATAG }\end{array}$ & $\begin{array}{l}159 \\
157-204\end{array}$ & 53 & 5 & JX193609 & $a, b$ \\
\hline Ed13 & $\begin{array}{l}(\mathrm{AC})_{6}(\mathrm{AG})_{6} \\
\mathrm{CG}(\mathrm{AG})_{5}\end{array}$ & $\begin{array}{l}\text { F: ACACACACACACAGAGAGAGAG } \\
\text { R: GGGAGATAGAGATAGAGACG }\end{array}$ & $\begin{array}{l}184 \\
174-199\end{array}$ & 55 & 4 & JX193610 & \\
\hline Ed14 & $(\mathrm{AC})_{6}(\mathrm{AG})_{6}$ & $\begin{array}{l}\text { F: ACACACACACACAGAGAGAGAG } \\
\text { R: ATTTCATTTGGTGGGCTTT }\end{array}$ & $\begin{array}{l}284 \\
284-308\end{array}$ & 55 & 4 & JX193611 & \\
\hline Ed15 & $(\mathrm{AC})_{6}(\mathrm{AG})_{8}$ & $\begin{array}{l}\text { F: ACACACACACACAGAGAGAGAG } \\
\text { R: ATCCTTTTTAGATTTCGTTTTA }\end{array}$ & $\begin{array}{l}195 \\
190-223\end{array}$ & 54 & 5 & JX193612 & \\
\hline Ed16 & $(\mathrm{AC})_{6}(\mathrm{AG})_{11}$ & $\begin{array}{l}\text { F: ACACACACACACAGAGAGAGAG } \\
\text { R:TACCACATAAACAAACCATT }\end{array}$ & $\begin{array}{l}386 \\
376-411\end{array}$ & 54 & 9 & JX193613 & \\
\hline Ed17 & $(\mathrm{AC})_{6}(\mathrm{AG})_{12}$ & $\begin{array}{l}\text { F: ACACACACACACAGAGAGAGAG } \\
\text { R:TTATCAAAAAATCAACAAAT }\end{array}$ & $\begin{array}{l}291 \\
280-322\end{array}$ & 53 & 11 & JX193614 & \\
\hline Ed18 & $\begin{array}{l}(\mathrm{AC})_{6}(\mathrm{AG})_{6} \\
\mathrm{AC}(\mathrm{AG})_{3}\end{array}$ & $\begin{array}{l}\text { F: ACACACACACACAGAGAGAGAG } \\
\text { R:CGGTTATGCCACGGACTT }\end{array}$ & $\begin{array}{l}277 \\
271-298\end{array}$ & 56 & 4 & JX193615 & \\
\hline
\end{tabular}

Notes: The $a$ and $b$ represent the primers that can successfully amplify in $E$. sylvestris and $E$. japonicus

Table 1: Characteristics of 18 compound microsatellite loci developed for $E$. decipiens. Shown for each locus are the locus name, the forward $(F)$ and reverse (R) primer sequence, the optimized annealing temperature (Ta), allele size ranges, the total number of alleles per locus (A) and the GenBank accession number. Size ranges and the total number of alleles include all values detected within three $E$. decipiens populations used in this study (Table 2).

\begin{tabular}{|c|c|c|c|c|c|c|c|c|c|c|c|c|}
\hline \multirow[t]{2}{*}{ Locus } & \multicolumn{4}{|c|}{ Population JG (11) } & \multicolumn{4}{|c|}{ Population LHN(12) } & \multicolumn{4}{|c|}{ Population TB(12) } \\
\hline & $A$ & Ho & $\mathrm{He}$ & $P I C$ & $A$ & Ho & $\mathrm{He}$ & $P I C$ & $A$ & Ho & $\mathrm{He}$ & PIC \\
\hline $\mathrm{Ed} 1^{* *}$ & 9 & 0.818 & 0.905 & 0.849 & 8 & 0.583 & 0.848 & 0.789 & 8 & 0.750 & 0.859 & 0.800 \\
\hline $\mathrm{Ed}^{*}$ & 6 & 0.727 & 0.823 & 0.753 & 8 & 0.833 & 0.899 & 0.845 & 8 & 0.750 & 0.884 & 0.828 \\
\hline $\mathrm{Ed}^{\text {n.s }}$ & 5 & 0.818 & 0.797 & 0.720 & 6 & 0.917 & 0.855 & 0.794 & 7 & 0.667 & 0.837 & 0.777 \\
\hline $\mathrm{Ed} 4^{\mathrm{n} . \mathrm{s}}$ & 5 & 0.909 & 0.801 & 0.726 & 5 & 0.750 & 0.815 & 0.745 & 5 & 0.750 & 0.797 & 0.723 \\
\hline$E d 5^{n . s}$ & 7 & 0.727 & 0.874 & 0.813 & 5 & 0.833 & 0.815 & 0.746 & 6 & 0.750 & 0.797 & 0.731 \\
\hline Ed6* & 7 & 0.818 & 0.831 & 0.765 & 7 & 0.750 & 0.804 & 0.738 & 8 & 0.750 & 0.855 & 0.797 \\
\hline $\mathrm{Ed} 7^{*}$ & 7 & 0.818 & 0.866 & 0.803 & 7 & 0.833 & 0.884 & 0.828 & 7 & 0.667 & 0.833 & 0.770 \\
\hline $\mathrm{Ed}^{\text {n.s }}$ & 7 & 0.818 & 0.857 & 0.794 & 7 & 0.750 & 0.870 & 0.811 & 7 & 0.750 & 0.804 & 0.740 \\
\hline Ed9n.s & 5 & 0.818 & 0.827 & 0.756 & 5 & 0.750 & 0.812 & 0.741 & 5 & 0.750 & 0.819 & 0.750 \\
\hline Ed10** & 7 & 0.818 & 0.840 & 0.773 & 6 & 0.667 & 0.841 & 0.778 & 7 & 0.583 & 0.866 & 0.808 \\
\hline Ed11 n.s & 5 & 0.818 & 0.779 & 0.700 & 5 & 0.667 & 0.815 & 0.745 & 5 & 0.750 & 0.786 & 0.716 \\
\hline Ed12 & 5 & 0.818 & 0.766 & 0.687 & 5 & 0.583 & 0.808 & 0.737 & 5 & 0.750 & 0.830 & 0.762 \\
\hline Ed13 & 4 & 0.818 & 0.723 & 0.627 & 4 & 0.750 & 0.736 & 0.654 & 4 & 0.833 & 0.685 & 0.605 \\
\hline Ed14 & 4 & 0.818 & 0.775 & 0.691 & 4 & 0.750 & 0.764 & 0.683 & 4 & 0.833 & 0.764 & 0.683 \\
\hline Ed15 $5^{n . s}$ & 4 & 0.818 & 0.775 & 0.691 & 4 & 0.750 & 0.757 & 0.677 & 5 & 0.750 & 0.808 & 0.737 \\
\hline Ed16 $6^{n . s}$ & 9 & 0.818 & 0.853 & 0.791 & 6 & 0.750 & 0.851 & 0.790 & 6 & 0.750 & 0.819 & 0.753 \\
\hline $\operatorname{Ed} 17^{* *}$ & 10 & 0.818 & 0.909 & 0.854 & 7 & 0.833 & 0.884 & 0.828 & 9 & 0.667 & 0.902 & 0.850 \\
\hline Ed18 $18^{\text {ns }}$ & 4 & 0.818 & 0.740 & 0.651 & 4 & 0.833 & 0.761 & 0.678 & 4 & 0.750 & 0.772 & 0.691 \\
\hline
\end{tabular}

Notes: ${ }^{*},{ }^{* *}$ and ${ }^{* * *}$, significant departures from Hardy-Weinberg equilibrium at $P<0.05, P<0.01, P<0.001$, respectively.

n.s. $=$ not significant

Table 2: Results of initial primer screening in three populations of $E$ decipiens. Shown are locus name, the number of alleles per locus $(A)$, mean values of observed $(H o)$ and expected $(\mathrm{He})$ heterozygosity, and polymorphism information content $(P I C)$. The sample size for each population is shown in parentheses. 
Citation: Gong X, Ge G (2013) Characterization of Polymorphic Microsatellite Markers Isolated from Genomic DNA of Elaeocarpus decipiens Hemsly (Elaeocarpaceae). J Data Mining Genomics Proteomics 4: 141. doi:10.4172/2153-0602.1000141

Page 3 of 3

in JG, LHN and TB Mountains, respectively (Table 2). Six loci (Ed1, Ed2, Ed6, Ed7, Ed10 and Ed17) significantly deviated from HWE $(\mathrm{P}<0.05)$ due to heterozygote deficiency. In addition, significant linkage disequilibrium (LD) was not detected between any pair of loci. Microsatellite loci were all identified and their respective sequences were deposited in GenBank (Accession Nos. JX193598-JX193615). Details about the 18 microsatellite loci and their variability across the 35 individuals were summarized in Table 1. Additionally, crossamplification of the 18 prime pairs was performed in 2 individuals of E. sylvestris and E. japonicus. Of these primers, only four (Ed6, Ed9, Ed11 and Ed12) could be successfully transferred to the tested species (Table 1).

\section{Conclusion}

The approach used in this study substantially reduces time in comparison with the FIASCO (Fast Isolation by APLR of Sequences Containing Repeats) protocol. Because a common fluorescent compound SSR primer can be used in polymorphism analyses for different loci and different species and the fluorescent primer is rather expensive, this may save investigation costs [7]. These polymorphic microsatellite markers of $E$. decipiens should represent a useful tool to assess patterns of geographical molecular variation in E. decipiens at the population level, and across the species' ranges in south of Chinese mainland, Taiwan and the Ryukyu Archipelago. Moreover, studies have shown that microsatellite primers developed in one species could be cross-amplified in related taxa [8]. However, only three and four loci were successfully amplified in E. japonicus and E. sylvestris, respectively. Even so, cross-species amplification in E. sylvestris and E. japonicus has opened an opportunity for comparative studies among these species.
In addition, the use of these markers will facilitate the follow up introgression of favorable variation from E. sylvestris and E. japonicus into E. decipiens.

\section{Acknowledgment}

This research was supported by the Science Foundation of Jiangxi Province (grant no. 20114BAB204012) and Education Department of Jiangxi Province (GJJ10085).

\section{References}

1. Chen SW, Gao ZH, Yue CH, Ye JW, Liao BH (2001) Studies on respondent of some tree species as Elaeocarpus decipiens to stress of salt fog and its physiological characteristics. J Zhejiang University 27: 398-402.

2. Luo Z, Zhou G, Chen XH (2001) Isolation of high quality genomic DNA from plants. Hunan Yi Ke Da Xue Xue Bao 26: 178-180

3. Lian CL, Zhou ZH, Hogetsu T (2001) A simple method for developing microsatellite markers using amplified fragments of inter-simple sequence repeat (ISSR). J Plant Res 114: 381-385.

4. Clarke KR, Gorley RN (2001) Primer v5: User manual/tutorial Primer-E Ltd. Plymouth, UK.

5. Rousset F (2008) GenePop'007: A complete re-implementation of the GenePop software for Windows and Linux. Mol Ecol Resour 8: 103-106.

6. Kalinowski ST, Taper ML, Marshall TC (2007) Revising how the computer program cervus accommodates genotyping error increases success in paternity assignment. Mol Ecol 16: 1099-1106.

7. Lian CL, Wadud MA, Geng Q, Shimatani K, Hogetsu T (2006) An improved technique for isolating codominant compound microsatellite markers. J Plant Res 119: 415-417.

8. Guicking, D, Rana, TS, Blattner, FR, Weising, K (2006) Microsatellite markers for the palaeotropical pioneer tree genus Macaranga (Euphorbiaceae) and their cross-species transferability. Mol Ecol Notes 6: 245-248. 